\title{
The Importance of Writing Scoring Rubrics for Saudi EFL Teachers Classroom
}

\author{
Hayat Rasheed Alamri ${ }^{1}$, Rania Daifullah Adawi ${ }^{2}$ \\ ${ }^{1}$ College of Education, Taibah University, Saudi Arabia \\ ${ }^{2}$ Ministry of Education, Saudi Arabia \\ Correspondence: Rania Daifullah Adawi, Ministry of Education, Madinah, Saudi Arabia. Tel: 966-504-357-030, \\ 966-553-338-537.E-mail: hramri@taibahu.edu.sa,Wise-hint@hotmail.com
}

Received: November 16, 2021; Accepted: November 26, 2021; Published: November 29, 2021

\begin{abstract}
This mixed-method study explored the perspectives of Saudi EFL teachers concerning the use of Writing Scoring Rubrics (WSRs) to correct students' written work and instruct EFL writing classes. The study sample included 106 Saudi EFL teachers, who answered the twenty-one close-ended questions and the first open-ended question, with twenty-five answering the second open-ended question. The findings reveal that the teachers frequently employed in-class correction and feedback to correct their students' written work, with nearly one-third used assessment techniques that included WSRs, self-assessment, peer editing, journals, and portfolios. The results of the second question indicate that Saudi EFL teachers generally engage students in creating customized WSRs. The findings also revealed that Saudi EFL teachers consider WSRs beneficial to both students and teachers and might be viewed by some experienced EFL teachers as a practical correction or assessment method that improves students' writing. Therefore, this study contributes to a growing body of literature highlighting the importance of WSRs in teaching and assessing writing skills.
\end{abstract}

Keywords: Saudi EFL teachers, perspectives, writing scoring rubrics, writing skills

\section{Introduction}

\subsection{General Background}

As indicated by Anwar and Ahmed (2016) and Ibnian (2017), writing forms a vital skill requiring the development of ideas, employing knowledge, grammar, vocabulary, mechanics, and personal experience. Moreover, it integrates with other language skills, i.e., reading, listening, and speaking (Javid and Umer, 2014). Ahmed (2010) referred to writing skills as "a reflective activity that requires enough time to think about the specific topic and analyze and classify any background knowledge... (Requiring) a suitable language to structure these ideas in the form of coherent discourse" (p. 211).

Rass (2015) indicated that the acquisition of writing skills in the context of a second or foreign language (ESL/EFL) is complex, requiring a wide range of cognitive and linguistic methods and a balancing of numerous issues, i.e., purpose, content, writing mechanics, cohesiveness, and coherence. Setyowati and Sukmawan (2016) stated that writing is "a sophistical language skill since it requires the ability not only to tailor ideas, but also to construct acceptable sentences to create a meaningful, logical, and comprehensible work" (p.365).

These demands can lead to some challenges for non-native speakers (Onchera \& Manyasi, 2013; Ridha, 2012). Ibrahim and Nambiar (2011) identified weaknesses of structure, grammar, vocabulary, organization, and a lack of research skills in the academic writing of Malaysian postgraduate students. Ridha's (2012) study of eighty Iraqi EFL students revealed that the majority expressed their thoughts in their mother tongue and experienced the most significant difficulties with grammatical and mechanical aspects of the foreign language. Furthermore, Onchera and Manyasi's (2013) examination of writing skills in Kenyan classrooms, using observation, a student's selfevaluation, and interviews with 720 students and eighteen English language teachers, found that functional writing instruction was not always efficient or communicative, and teachers failed to provide in-depth instructions or correctness. Moreover, Rass (2015) identified that Arab EFL students tend to encounter difficulties in writing a well-developed paragraph, including: (1) omitting supporting material (i.e., instances and justifications); (2) L1 interference; and (3) a failure to use coordinators and transition words to construct a cohesive paragraph. 
Similarly, Setyowati and Sukmawan's (2016) study of fifty-seven EFL Indonesian students revealed that 58\% viewed writing in English as difficult and stressful. In addition, Ibnian (2017) indicated that most EFL Jordanian students face challenges: a lack of ideas, incorrect use of language mechanics; restricted vocabulary; grammar difficulties; and lack of teacher's help. Furthermore, Karim et al. (2017) employed a questionnaire with forty-three Bangladeshi tertiary level EFL students, finding that they struggled with: firstly, the writing stage of paragraphs, secondly, the reviewing and planning stages, and thirdly, the use of idioms, appropriate vocabulary, and antonyms. An additional study by Anh (2019) revealed that Thai EFL students experienced a lack of vocabulary, and limited grammar and writing skills.

In Saudi Arabia, Ansari (2012) identified that Saudi EFL students demonstrated insufficient knowledge of basic English and lacked adequate writing skills. Javid and Umer (2014) also highlighted issues in Saudi EFL classrooms, highlighting challenges in academic writing due to an inability to organize thoughts effectively and employ appropriate lexical items and syntax. Furthermore, Mohammad and Hazarika (2016) affirmed that Saudi EFL students memorize written paragraphs rather than develop their writing strategies. Additionally, Alshakhi's (2018) study of the English Language Institution (ELI) at King Abdulaziz University revealed that students tended to receive help with their writing assignments from tutors or high-achieving students. In addition, Ahmed (2019) identified common mistakes as including lack of paragraph unity, inappropriate tenses, omission of linking words, and incorrect selection of pronouns. Furthermore, Alzamil (2020) analyzed forty-eight compositions written by Saudi EFL students over two weeks, revealing a high rate of capitalization, spelling, and grammar errors. Moreover, Mohammed and Alshenqeeti (2020) indicated that Saudi EFL first-year undergraduates face a considerable mismatch between the L2 writing skills acquired in high school and the proficiency levels required for university courses.

These challenges highlight the significance of teaching methods and assessment (Ansari, 2012), with Anwar and Ahmed (2016) finding that students' writing performance depends on their teachers' strategies. Several studies (Gulzar et al., 2017; Ketabi, 2015; Sharma, 2019; Tseng, 2018) have attempted to implement various writing assessment techniques, including dictation, teacher's correction; constructive feedback; self-correction; peer editing; journals; and portfolios. Recent evidence (Becker, 2016; Larkin, 2015; Ningsih, 2016) suggests that Writing Scoring Rubrics (WSRs) can prove beneficial for establishing effective correction criteria and opportunities for learners to undertake self-assessment before submitting written materials.

\subsection{Writing scoring rubrics (WSRs.): Pros and Cons}

A rubric is generally used as a scoring guide to accomplishing several instructional purposes, i.e., descriptive, reflective, critical thinking, projects, and presentations (Chowdhury, 2018), being defined by Chowdhury (2019) as "a scoring tool that sets criteria and standards for the students' expected performance in a specific task, across 3 to 5 levels" (p.62).

Scoring rubrics are also acknowledged as effective for assessing writing tasks. Moskal (2000) stated that a WSR rubric is "a descriptive scoring scheme developed to judge the quality of a given writing sample depending upon established criteria" (p.1). Gulzar et al. (2006) pointed out that WSRs help teachers guide students to understand the details related to the writing task and limit any opportunity to ignore small mistakes. Qasim and Qasim (2015) assumed that the primary role of WSRs was to measure students' understanding of instructions and obtain detailed feedback during self-assessment. Likewise, Bradford et al. (2016) recommended WSRs as providing opportunities for self-monitoring, while Kulprasit (2017) considered WSRs a valuable source of feedback for students and teachers.

A rubric includes three significant aspects: (1) performance criteria, (2) rating scale, and (3) indicators. Aldukhayel (2017), Becker (2016), and Rini and Purnawarman (2018) recommended comprising information on assessment criteria to engage students and promote realistic expectations. Chan and Ho (2019) considered WSRs enhanced transparency by informing students of those aspects assessed in each task. Moreover, Narvaez et al. (2019) revealed that WSRs facilitate evaluating and reporting students' achievements and levels.

Existing research has recognized the critical role played by WSRs. For instance, Jeong (2015) found WSRs prompted a focus on comprehension and the author's voice among teacher-raters from a large private Korean University. In addition, Qasim and Qasim's (2015) study of Pakistani EFL teachers found that four of their six participants $(66.7 \%)$ recommended using a scoring rubric to address students' mechanical writing errors. Furthermore, Turgut and Kayaoğlu's (2015) study found that rubrics assisted Turkish EFL students in appreciating the criteria of excellent writing. Moreover, Kulprasit (2016) revealed that raising awareness of the positive impact of WSR improved Thai EFL students' attitudes towards rubrics as a practical tool improved their writing proficiency and language production. 
Recently, a considerable degree of literature has examined the Saudi context. For example, Aldukhayel (2017) used a questionnaire to explore the clarity and familiarity of scoring rubrics used to assess writing achievement in a Saudi university Preparatory Year Program (PYP). Data from 281 Saudi EFL students found they were unfamiliar with the pedagogical role of WSRs. Gulzar et al. (2017) also established the benefits of rubrics for assessing the writing tasks of 100 students from a Public Sector University, indicating an essential difference in the students' marks when assessed with and without WSR. Furthermore, Rini and Purnawarman's (2018) mixed-method study of sixteen Indonesian EFL teachers found a positive response to utilizing teacher-made rubrics. Similarly, Sharma (2019) explored the views of forty-eight Saudi EFL teachers at Jazan University, demonstrating that $93 \%$ believed WSRs consistently improve grading, as well as promoting: (a) students' autonomy; (b) ownership of their work; and (d) learning efficacy. Moreover, Mahmoudi and Buğra (2020) open-ended questionnaire and focus group discussion with thirty-six pre-service teachers found that writing rubrics and face-to-face feedback improved students' writing skills.

\subsection{Statement of the Problem}

Several studies (Ansari, 2012; Anwar \& Ahmed, 2016; Gulzar et al., 2017; Ketabi, 2015; Tseng, 2018) have investigated EFL teachers' writing challenges, such as inappropriate teaching methods, insufficient teaching methods, insufficient time for feedback, and correction, and inappropriate strategies. These are also issues facing teachers in Saudi Arabia, Saudi EFL students experiencing difficulties in composing well-organized essays, including clear paragraphs with accurate vocabulary, spelling, punctuation, and grammar (Alshakhi, 2018; Alzamil, 2020; Ansari, 2012; Mohammad \& Hazarika, 2016; Mohammed \& Alshenqeeti, 2020). The above studies identified this aspect as arising from ineffective methods and strategies, insufficient time to correct errors, and providing constructive individual and group feedback.

Despite the crucial role of scoring rubrics in improving teaching and learning, few previous studies (Bradford et al., 2016; Mahmoudi \& Buğra, 2020; Turgut \& Kayaoğlu, 2015) have investigated the implementation of WSRs, which are also under-used in Saudi EFL writing classrooms. Therefore, this current mixed-method study examines Saudi EFL teachers' views concerning the benefits of WSRs and the practical implications of their implementation in EFL writing classrooms.

\subsection{Research Questions}

The study answers the following questions:

1. What are the Saudi EFL teachers' perspectives on the importance of WSRs to the learners?

2. What are the Saudi EFL teachers' perspectives on the importance of WSRs to the teachers?

3. What are the practical implications of WSRs in correcting students' writing?

4. How do the EFL teachers validate their students' writing improvement after using WSRs?

\section{Method}

Creswell (2012, p. 535) stated that mixed-method research "is not simply collecting two distinct 'strands' of research — qualitative and quantitative. It consists of merging, integrating, linking, or embedding the two 'strands'." Thus, the quantitative data for this research was gathered utilizing a questionnaire and qualitative data through open-ended questions.

\subsection{Population and Research Sample}

The study population comprised 1470 male and female Saudi EFL teachers in Madinah, Saudi Arabia, during the first semester of the 2020 academic year. The study sample included 106 Saudi EFL teachers (7.21\%) who participated voluntarily in the questionnaire after receiving the online form of the questionnaire that had been distributed officially by the Planning and Development Department at the Directorate of Education in Madinah. The sample consisted of $62(58.5 \%)$ female and $44(41.5 \%)$ male EFL teachers. Table 1 demonstrates the other demographic information mentioned in the first section.

Table 1. Characteristics of the research sample

\begin{tabular}{|c|c|c|c|c|}
\hline \multirow{2}{*}{ Variables } & \multirow[b]{3}{*}{ Bachelor } & Frequencies & \multirow{2}{*}{$\%$} & \multirow{2}{*}{$\begin{array}{l}\text { Total } \\
(100 \%)\end{array}$} \\
\hline & & $\mathrm{N}=106$ & & \\
\hline \multirow[t]{3}{*}{ Degrees } & & 90 & 84.9 & 106 \\
\hline & Diploma & 1 & .9 & $(100 \%)$ \\
\hline & Master & 15 & 14.2 & \\
\hline Teaching Experience & $1-5$ & 12 & 11.3 & 106 \\
\hline
\end{tabular}




\begin{tabular}{lllll}
\hline & $6-10$ & 20 & 18.9 & $(100 \%)$ \\
$11-15$ & 20 & 18.9 & \\
School Types & 16 & 35 & 33.0 & \\
& More than 20 & 19 & 17.9 & \\
& Elementary & 25.5 & 106 \\
& Elementary \& Intermediate & 2.8 & $(100 \%)$ \\
& Elementary, Intermediate \& Secondary & 3 & 2.8 & \\
Elementary \& Secondary & 2 & 1.9 & \\
& Intermediate & 26 & 24.5 & \\
& Intermediate \& Secondary & 2 & 1.9 & \\
Secondary & 43 & 40.6 & \\
\hline
\end{tabular}

The study sample differed in their academic subject and level, years of experience, and type of school. Teachers with a wide range of degrees and years of experience might demonstrate a greater depth of knowledge through their responses to the open-ended questions regarding how they use scoring rubrics.

\subsection{Instrumentation}

The researchers initially devised a questionnaire as the primary research instrument comprised of four sections, based on previous literature (Aldukhayel, 2017; Kulprasit, 2016; Qasim \& Qasim, 2015). The first section covered demographic information to describe the research sample. Its results have already been mentioned. The second section consisted of three closed questions concerning the teachers' general background in relation to rubrics (see Figure $1 \&$ Table 2).

\begin{tabular}{r|c|c|} 
Teacher's in-class quick correction and... & \multicolumn{3}{|c}{$\mathbf{8 5}$} & $\mathbf{8 0 . 2}$ \\
Customized writing scoring rubrics & $\mathbf{2 8}$ & $\mathbf{2 6 . 4}$ \\
Student self-assessment & $\mathbf{2 7}$ & $\mathbf{2 5 . 5}$ \\
Peer editing & $\mathbf{1 8}$ & $\mathbf{1 7 . 0}$
\end{tabular}

Alternative assessment techniques (e.g.,...6 5.7

\section{- Frequencies $\quad$ Percentages}

Figure 1. Descriptive results of the teachers' techniques to correct writing tasks

The results of the first question in section 2, "What techniques do EFL teachers usually use to correct students' writing tasks?" show that about $80.2 \%$ generally employed in-class correction and feedback, with about $26.4 \%$ using customized WSRs; (25.5\%) students' self-assessment; (17.0\%) peer editing; and 5.7\% alternative assessment techniques, i.e., journals or portfolios. Regarding the other two questions, Table 2 illustrates the sample responses.

Table 2. Descriptive results of the teachers' initial background of using WSRs

\begin{tabular}{|c|c|c|c|c|c|c|c|c|}
\hline \multirow[t]{2}{*}{ Questions } & \multicolumn{5}{|c|}{ The Scale } & \multirow[t]{2}{*}{ Mean } & \multirow[t]{2}{*}{ S.D. } & \multirow[t]{2}{*}{ Level } \\
\hline & Always & Usually & Sometimes & Seldom & Never & & & \\
\hline $\begin{array}{l}\text { 2. How often do you use } \\
\text { rubrics to correct students' } \\
\text { writing tasks? }\end{array}$ & $\begin{array}{l}19 \\
(17.9)\end{array}$ & $\begin{array}{l}29 \\
(27.4)\end{array}$ & $\begin{array}{l}38 \\
(35.8)\end{array}$ & $\begin{array}{l}13 \\
(12.3)\end{array}$ & $\begin{array}{l}7 \\
(6.6)\end{array}$ & 3.38 & 1.12 & Sometimes \\
\hline $\begin{array}{l}\text { 3. If you use customized } \\
\text { rubrics, do you engage } \\
\text { students in creating them } \\
\text { for better writing } \\
\text { performance? }\end{array}$ & $\begin{array}{l}24 \\
(22.6)\end{array}$ & $\begin{array}{l}36 \\
(34.0)\end{array}$ & $\begin{array}{l}24 \\
(22.6)\end{array}$ & $\begin{array}{l}9 \\
(8.5)\end{array}$ & $\begin{array}{l}13 \\
(12.3)\end{array}$ & 3.46 & 1.27 & Usually \\
\hline
\end{tabular}


The results reveal Saudi EFL teachers indicated that they 'sometimes' use rubrics with a mean score (3.38). The answer 'Never' shows a minor percentage (6.6\%). For the third question, EFL teachers 'Usually' engage students in constructing writing rubrics, with only twenty-four (22.6\%) engaging students in creating customized WSRs, with a mean score (3.46).

The third section of the questionnaire included twenty-one close-ended questions and one open-ended question to provide in-depth insights into the practical implications of scoring rubrics for EFL writing correction. The participants ranked their perspectives on a 5-point Likert scale (Strongly Disagree $=1$, Disagree $=2$, Neutral=3, Agree $=4 \&$ Strongly Agree $=5$ ). Another open-ended question in the fourth section seeks to explore EFL teachers' perspectives on whether or not their students' writing competency levels have improved as a result of using rubrics in assessment or feedback.

In round one, the three questionnaire sections were submitted to the research sample in one online form. Only 100 (94.34\%) responded to the first open-ended question. In round two, the second open-ended question in section four was re-submitted via respondents' e-mails to 99 after excluding 7 participants who never implemented WSRs. Thus, twenty-five (25.3\%) participants responded to the second open-ended question.

\subsubsection{Validity}

The questionnaire was validated by five EFL experts, resulting in a small number of changes. For example, the first section decreased from five to three closed questions, and the third section was divided into two dimensions: one consisting of sixteen items covering the importance of scoring rubric for students, and the other of seven items covering the importance of the scoring rubric for the teachers. The experts suggested adding two more items to this section, resulting in the fifth part being increased to two open-ended.

\subsubsection{Reliability}

A pilot study was conducted with twenty-five Saudi EFL teachers to compute the questionnaire's reliability and internal consistency. Pearson correlation was employed to describe the strength and direction of the relationship between the items, indicating a positive, direct, and significant relationship between the sixteen items of the first dimension with values ranged $(\mathrm{r}=.569-.856)$. Similarly, the correlation coefficient of the seven items of the second dimension indicated a positive, direct, and significant relationship $(\mathrm{r}=.709-.923)$. The internal consistency of all items was measured using Cronbach's alpha coefficient, revealing that all twenty-three items had a good level of internal consistency and reliability $(0.961)$, i.e., the reliability of the sixteen items in the first dimension $=0.945$ and for the seven items in the second dimension $=0.933$.

\subsubsection{Data collection}

On November 23, 2020, the questionnaire was officially given to Saudi EFL teachers in Madinah, Saudi Arabia, with 106 responses returned after two weeks. Seven participants were excluded, followed by the researchers submitting the second open-ended question to ninety-nine EFL teachers on December 19, 2020, to determine if they had identified an enhancement in students' writing proficiency levels, of which twenty-five proved willing to participate.

\subsubsection{Data analysis}

The data from the questionnaire was examined using descriptive statistics (frequencies, percentages, means, and standard deviations). For the first open-ended question, the researchers assigned initial codes to condense the mass of data into preliminary analytic categories (implications for students, implications for teachers, and neutral responses). This categorization is based on the coding and concept formation method (Neuman, 2014, p. 480). Similarly, the researchers classified the raw data of the second open-ended question into the following conceptual categories (noticeable improvement, non-noticeable improvement, and neutral responses) to represent any enhancement noticed by the EFL teachers in their students' writing proficiency levels after using rubrics as a feedback or a self-assessment technique. Finally, the researchers intensively revised and examined the assigned codes to identify and select the data to illustrate the categories chosen for both questions. The coded and categorized qualitative data were presented using frequencies and percentages. Statistical analysis was performed using SPSS software (version 25).

\section{Results}

This mixed-method study explored Saudi EFL teachers' perspectives on implementing WSRs to correct students' written work and provide in-depth insights into the practical implications of that implementation. Frequency, percentages, means, and standard deviations were computed to answer the research questions. 


\subsection{Results of the Teachers' Perspectives on the Importance of Using Scoring Rubrics to Learners}

Descriptive statistics were computed to answer the first research question, "What are the Saudi EFL teachers' perspectives on the importance of WSRs to the learners?" (see Table 3). The results ranked from high to low frequency of use by considering mean (M) and standard deviation (S.D.) for each item of the questionnaire's responses.

Table 3. Descriptive Results of the Teachers' Perspectives on the Importance of Using WSRS to Learners

\begin{tabular}{|c|c|c|c|c|c|c|c|c|}
\hline \multirow[t]{2}{*}{ Statements } & \multicolumn{5}{|l|}{ The Scale } & \multirow[t]{2}{*}{ Mean } & \multirow[t]{2}{*}{ S.D. } & \multirow[t]{2}{*}{ Level } \\
\hline & $\begin{array}{l}\text { Strongly } \\
\text { Disagree }\end{array}$ & Disagree & Neutral & Agree & $\begin{array}{l}\text { Strongly } \\
\text { Agree }\end{array}$ & & & \\
\hline $\begin{array}{l}\text { 1. Provide learners with } \\
\text { constructive feedback. }\end{array}$ & $\begin{array}{l}1 \\
(0.9)\end{array}$ & - & $\begin{array}{l}20 \\
(18.9)\end{array}$ & $\begin{array}{l}29 \\
(27.4)\end{array}$ & $\begin{array}{l}56 \\
(52.8)\end{array}$ & 4.31 & 0.84 & $\begin{array}{l}\text { Strongly } \\
\text { Agree }\end{array}$ \\
\hline $\begin{array}{l}\text { Encourage learners to } \\
\text { think critically in their } \\
\text { written tasks. }\end{array}$ & $\begin{array}{l}1 \\
(0.9)\end{array}$ & $\begin{array}{l}2 \\
(1.9)\end{array}$ & $\begin{array}{l}18 \\
(17.0)\end{array}$ & $\begin{array}{l}31 \\
(29.2)\end{array}$ & $\begin{array}{l}54 \\
(50.9)\end{array}$ & 4.27 & 0.88 & $\begin{array}{l}\text { Strongly } \\
\text { Agree }\end{array}$ \\
\hline $\begin{array}{l}\text { 3. Support learners' self- } \\
\text { assessment approach. }\end{array}$ & $\begin{array}{l}1 \\
(0.9)\end{array}$ & $\begin{array}{l}4 \\
(3.8)\end{array}$ & $\begin{array}{l}19 \\
(17.9)\end{array}$ & $\begin{array}{l}27 \\
(25.5)\end{array}$ & $\begin{array}{l}55 \\
(51.9)\end{array}$ & 4.24 & 0.94 & $\begin{array}{l}\text { Strongly } \\
\text { Agree }\end{array}$ \\
\hline $\begin{array}{l}\text { 4. Assist learners to track } \\
\text { their continuous progress in } \\
\text { writing. }\end{array}$ & $\begin{array}{l}1 \\
(0.9)\end{array}$ & $\begin{array}{l}3 \\
(2.8)\end{array}$ & $\begin{array}{l}19 \\
(17.9)\end{array}$ & $\begin{array}{l}30 \\
(28.3)\end{array}$ & $\begin{array}{l}53 \\
(50.0)\end{array}$ & 4.24 & 0.91 & $\begin{array}{l}\text { Strongly } \\
\text { Agree }\end{array}$ \\
\hline $\begin{array}{l}\text { 5. Help learners to } \\
\text { explore their spelling } \\
\text { mistakes. }\end{array}$ & $\begin{array}{l}1 \\
(0.9)\end{array}$ & $\begin{array}{l}1 \\
(.9)\end{array}$ & $\begin{array}{l}23 \\
(21.7)\end{array}$ & $\begin{array}{l}28 \\
(26.4)\end{array}$ & $\begin{array}{l}53 \\
(50.0)\end{array}$ & 4.24 & 0.89 & $\begin{array}{l}\text { Strongly } \\
\text { Agree }\end{array}$ \\
\hline $\begin{array}{l}\text { 6. Guide learners to } \\
\text { discover weaknesses and } \\
\text { strengths in writing. }\end{array}$ & - & $\begin{array}{l}6 \\
(5.7)\end{array}$ & $\begin{array}{l}16 \\
(15.1)\end{array}$ & $\begin{array}{l}34 \\
(32.1)\end{array}$ & $\begin{array}{l}50 \\
(47.2)\end{array}$ & 4.21 & 0.90 & $\begin{array}{l}\text { Strongly } \\
\text { Agree }\end{array}$ \\
\hline $\begin{array}{l}\text { 7. Encourage learners to } \\
\text { use punctuation correctly. }\end{array}$ & - & $\begin{array}{l}4 \\
(3.8)\end{array}$ & $\begin{array}{l}24 \\
(22.6)\end{array}$ & $\begin{array}{l}25 \\
(23.6)\end{array}$ & $\begin{array}{l}53 \\
(50.0)\end{array}$ & 4.20 & 0.92 & $\begin{array}{l}\text { Strongly } \\
\text { Agree }\end{array}$ \\
\hline $\begin{array}{l}\text { 8. Provide learners with } \\
\text { evidence of their } \\
\text { performance in writing. }\end{array}$ & - & $\begin{array}{l}1 \\
(.9)\end{array}$ & $\begin{array}{l}24 \\
(22.6)\end{array}$ & $\begin{array}{l}34 \\
(32.1)\end{array}$ & $\begin{array}{l}47 \\
(44.3)\end{array}$ & 4.20 & 0.82 & $\begin{array}{l}\text { Strongly } \\
\text { Agree }\end{array}$ \\
\hline $\begin{array}{l}\text { 9. Help learners to } \\
\text { explore } \\
\text { mistakes. }\end{array}$ & $\begin{array}{l}2 \\
(1.9)\end{array}$ & $\begin{array}{l}3 \\
(2.8)\end{array}$ & $\begin{array}{l}18 \\
(17.0)\end{array}$ & $\begin{array}{l}33 \\
(31.1)\end{array}$ & $\begin{array}{l}50 \\
(47.2)\end{array}$ & 4.19 & .95 & Agree \\
\hline $\begin{array}{l}\text { 10. Provide learners with } \\
\text { analysis skills of their } \\
\text { writing mistakes. }\end{array}$ & - & $\begin{array}{l}3 \\
(2.8)\end{array}$ & $\begin{array}{l}18 \\
(17.0)\end{array}$ & $\begin{array}{l}41 \\
(38.7)\end{array}$ & $\begin{array}{l}44 \\
(41.5)\end{array}$ & 4.19 & 0.82 & Agree \\
\hline $\begin{array}{l}\text { 11. Make learners focus on } \\
\text { the writing mechanics. }\end{array}$ & $\begin{array}{l}1 \\
(.9)\end{array}$ & $\begin{array}{l}4 \\
(3.8)\end{array}$ & $\begin{array}{l}19 \\
(17.9)\end{array}$ & $\begin{array}{l}34 \\
(32.1)\end{array}$ & $\begin{array}{l}48 \\
(45.3)\end{array}$ & 4.17 & 0.92 & Agree \\
\hline $\begin{array}{l}\text { 12. Help learners achieve } \\
\text { coherence in writing. }\end{array}$ & $\begin{array}{l}1 \\
(0.9)\end{array}$ & $\begin{array}{l}2 \\
(1.9)\end{array}$ & $\begin{array}{l}23 \\
(21.7)\end{array}$ & $\begin{array}{l}33 \\
(31.1)\end{array}$ & $\begin{array}{l}47 \\
(44.3)\end{array}$ & 4.16 & 0.90 & Agree \\
\hline $\begin{array}{l}\text { 13. Help learners to pay } \\
\text { more attention to their } \\
\text { handwriting. }\end{array}$ & - & $\begin{array}{l}6 \\
(5.7)\end{array}$ & $\begin{array}{l}21 \\
(19.8)\end{array}$ & $\begin{array}{l}29 \\
(27.4)\end{array}$ & $\begin{array}{l}50 \\
(47.2)\end{array}$ & 4.16 & 0.94 & Agree \\
\hline $\begin{array}{l}\text { 14. Introduce WSR as an } \\
\text { authentic assessment } \\
\text { technique to the learners. }\end{array}$ & - & $\begin{array}{l}4 \\
(3.8)\end{array}$ & $\begin{array}{l}19 \\
(17.9)\end{array}$ & $\begin{array}{l}40 \\
(37.7)\end{array}$ & $\begin{array}{l}43 \\
(40.6)\end{array}$ & 4.15 & 0.85 & Agree \\
\hline $\begin{array}{l}\text { 15. Evoke learners' high- } \\
\text { order thinking skills. }\end{array}$ & - & $\begin{array}{l}2 \\
(1.9)\end{array}$ & $\begin{array}{l}24 \\
(22.6)\end{array}$ & $\begin{array}{l}37 \\
(34.9)\end{array}$ & $\begin{array}{l}43 \\
(40.6)\end{array}$ & 4.14 & 0.83 & Agree \\
\hline $\begin{array}{l}\text { 16. Clarify critical qualities } \\
\text { for written texts. }\end{array}$ & $\begin{array}{l}1 \\
(0.9)\end{array}$ & $\begin{array}{l}3 \\
(2.8)\end{array}$ & $\begin{array}{l}23 \\
(21.7)\end{array}$ & $\begin{array}{l}36 \\
(34.0)\end{array}$ & $\begin{array}{l}43 \\
(40.6)\end{array}$ & 4.10 & 0.90 & Agree \\
\hline
\end{tabular}


Table 3 shows that eight items revealed substantial agreement between Saudi EFL teachers that WSRs provide constructive feedback (Item $1, \mathrm{M}=4.31 ; \mathrm{SD}=0.84$ ) and encourage students to critically consider their work (Item $2, \mathrm{M}=4.27 ; \mathrm{SD}=0.88)$. Identical mean scores $(\mathrm{M}=4.24)$ indicated they also agreed that using WSRs can assist with learners' self-assessment and progress and spelling issues. The findings also revealed a substantial agreement (Item $6, \mathrm{M}=4.21 ; \mathrm{SD}=0.90$ ) concerning the value of WSRs in guiding learners to recognize their writing weaknesses and strengths. Furthermore, there was an equally strong agreement on items 7 and $8(M=4.20)$ concerning the usefulness of WSRs for encouraging learners to use correct punctuation and providing evidence of their writing ability.

The remaining eight items concerned the relevance of WSRs to learners, with equal mean scores for items 9 and $10(\mathrm{M}=4.19)$, demonstrating that the Saudi EFL teachers agreed that WSRs assisted learners to explore grammatical problems and analyze their mistakes, while the mean score for Item $11,(\mathrm{M}=4.17 ; \mathrm{SD}=0.92)$ suggested a focus on writing mechanics. Additionally, similar mean scores for items 12 and $13(\mathrm{M}=4.16)$ indicated they viewed WSRs as vital for assisting learners to develop coherence and pay greater attention to their handwriting. The mean scores for items 14 and $15(\mathrm{M}=4.15 ; \mathrm{SD}=0.85 ; \mathrm{M}=4.14 ; \mathrm{SD}=0.83)$ indicated the need to familiarize learners with WSR as an authentic evaluation technique promoting high-order thinking skills during the writing process. Finally, a mean score for Item $16(\mathrm{M}=4.21 ; \mathrm{SD}=0.90)$ showed EFL teachers agreed that WSRs highlight critical qualities for written texts.

\subsection{Results of the teachers' Perspectives on the Importance of Using Scoring Rubrics to Teachers}

To answer the second research question, "What are the Saudi EFL teachers' perspectives on the importance of WSRs to the teachers?" descriptive statistics were computed as presented in Table 4.

Table 4. Descriptive Results of the Teachers' Perspectives on the Importance of Using WSRs to Teachers

\begin{tabular}{|c|c|c|c|c|c|c|c|c|}
\hline \multirow[t]{2}{*}{ Statements } & \multicolumn{5}{|c|}{ The Scale } & \multirow[t]{2}{*}{ Mean } & \multirow[t]{2}{*}{ S.D. } & \multirow[t]{2}{*}{ Level } \\
\hline & $\begin{array}{l}\text { Strongly } \\
\text { Disagree }\end{array}$ & Disagree & Neutral & Agree & $\begin{array}{c}\text { Strongly } \\
\text { Agree }\end{array}$ & & & \\
\hline $\begin{array}{l}\text { 1. Assist teachers to } \\
\text { discover students' } \\
\text { creativity in writing. }\end{array}$ & $\begin{array}{c}1 \\
(0.9)\end{array}$ & $\begin{array}{c}1 \\
(0.9)\end{array}$ & $\begin{array}{c}19 \\
(17.9)\end{array}$ & $\begin{array}{c}37 \\
(34.9)\end{array}$ & $\begin{array}{c}48 \\
(45.3)\end{array}$ & 4.23 & 0.84 & $\begin{array}{l}\text { Strongly } \\
\text { Agree }\end{array}$ \\
\hline $\begin{array}{l}\text { 2. Make writing learning } \\
\text { outcomes measurable. }\end{array}$ & $\begin{array}{c}1 \\
(0.9)\end{array}$ & $\begin{array}{c}3 \\
(2.8)\end{array}$ & $\begin{array}{c}19 \\
(17.9)\end{array}$ & $\begin{array}{c}35 \\
(33.0)\end{array}$ & $\begin{array}{c}48 \\
(45.3)\end{array}$ & 4.19 & 0.90 & Agree \\
\hline $\begin{array}{l}\text { 3. Make the writing } \\
\text { assessment process fair. }\end{array}$ & $\begin{array}{c}1 \\
(0.9)\end{array}$ & - & $\begin{array}{c}24 \\
(22.6)\end{array}$ & $\begin{array}{c}35 \\
(33.0)\end{array}$ & $\begin{array}{c}46 \\
(43.4)\end{array}$ & 4.18 & 0.85 & Agree \\
\hline $\begin{array}{l}\text { 4. Guide teachers to design } \\
\text { appropriate activities for } \\
\text { teaching writing skills. }\end{array}$ & $\begin{array}{c}1 \\
(0.9)\end{array}$ & $\begin{array}{c}3 \\
(2.8)\end{array}$ & $\begin{array}{c}21 \\
(19.8)\end{array}$ & $\begin{array}{c}38 \\
(35.8)\end{array}$ & $\begin{array}{c}43 \\
(40.6)\end{array}$ & 4.12 & 0.89 & Agree \\
\hline $\begin{array}{l}\text { 5. Inspire teachers to use } \\
\text { innovative teaching } \\
\text { writing techniques. }\end{array}$ & - & $\begin{array}{c}4 \\
(3.8)\end{array}$ & $\begin{array}{c}21 \\
(19.8)\end{array}$ & $\begin{array}{c}39 \\
(36.8)\end{array}$ & $\begin{array}{c}42 \\
(39.6)\end{array}$ & 4.12 & 0.86 & Agree \\
\hline $\begin{array}{l}\text { 6. Allow teachers to reflect } \\
\text { on students' progress. }\end{array}$ & $\begin{array}{c}1 \\
(0.9)\end{array}$ & $\begin{array}{c}4 \\
(3.8)\end{array}$ & $\begin{array}{c}18 \\
(17.0)\end{array}$ & $\begin{array}{c}42 \\
(39.6)\end{array}$ & $\begin{array}{c}41 \\
(38.7)\end{array}$ & 4.11 & 0.89 & Agree \\
\hline $\begin{array}{l}\text { 7. Help teachers to } \\
\text { determine accurately } \\
\text { learners' writing } \\
\text { outcomes. }\end{array}$ & $\begin{array}{c}1 \\
(0.9)\end{array}$ & $\begin{array}{c}2 \\
(1.9)\end{array}$ & $\begin{array}{c}24 \\
(22.6)\end{array}$ & $\begin{array}{c}37 \\
(34.9)\end{array}$ & $\begin{array}{c}42 \\
(39.6)\end{array}$ & 4.10 & 0.88 & Agree \\
\hline
\end{tabular}

These findings demonstrate that EFL teachers expressed substantial agreement on the importance of WSRs, primarily for establishing their students' creativity (Item $1, \mathrm{M}=4.23$; $\mathrm{SD}=0.84$ ). Moreover, the results ensure writing learning outcomes are measurable and the evaluation process fair, with close mean scores (items 2 and 3 , $\mathrm{M}=4.19 ; \mathrm{SD}=0.90 \& \mathrm{M}=4.18 ; \mathrm{SD}=0.85$, as well as equal mean scores (items 4 and $5, \mathrm{M}=4.12$ ) showing their benefits for designing appropriate writing exercises and inspiring them to utilize innovative teaching strategies. 
Similarly, the participants agreed that WSRs allow teachers to reflect on students' progress and accurately identify writing outcomes with close mean scores (Item 6, $\mathrm{M}=4.11 ; \mathrm{SD}=0.89$ and (Item 7, $\mathrm{M}=4.10 ; \mathrm{SD}=0.88$ ).

\subsection{Results of the Teachers' Perspectives on the Practical Implications of WSRs}

The responses collected from the first open-ended question to answer the third research question: "What are the practical implications of WSRs in correcting students' writing?", were grouped into implications of implementing WSRs related to (a) students; (b) teachers; and (c) neutral responses, based on responses to the first open-ended question (see Figure 2).

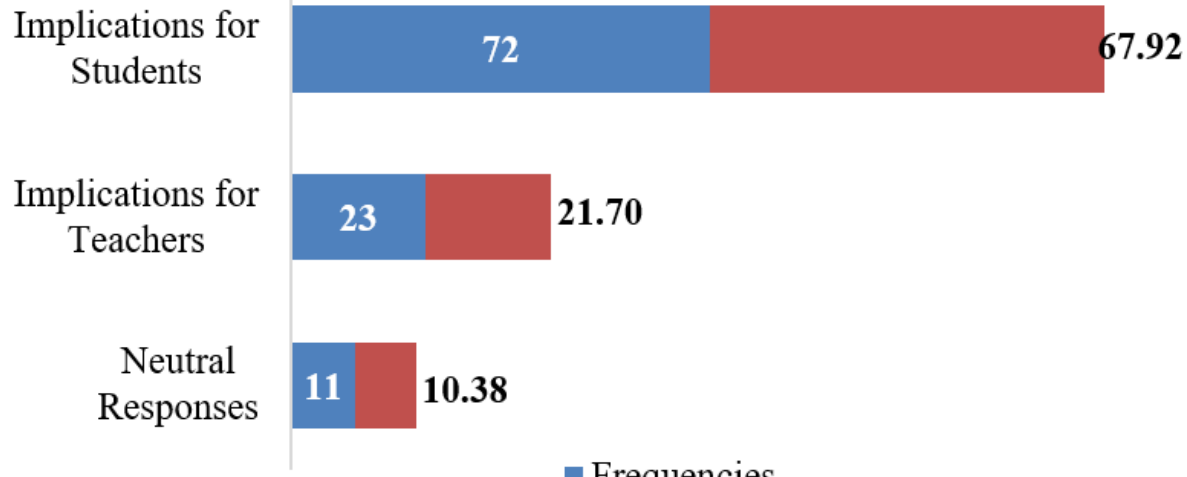

Figure 2. Descriptive results of the teachers' perspectives on the implications of WSRs

Figure 2 demonstrates that most participants (i.e., seventy-two (67.92\%)) considered WSRs as primarily benefiting students, with only twenty-three responses (21.70\%) reporting benefits for EFL teachers and about eleven (10.38\%) remaining neutral.

The comments below reflect the perspective of EFL teachers concerning the practical impact of WSRs.

"Rubrics usually provide students with an outline and steps to write better."

"(Rubrics) have made students more creative, evoked their critical thinking, and raised their motivation toward writing classes."

"WSRs encourage students to think critically in their writing tasks."

"(Using WSRs has) improved the students' writing skills and helped them be aware of their mistakes, which positively affected the other language skills."

"Writing rubrics have had a positive impact, since students have a clear idea of their performance."

"Rubrics give students enough time to write and follow-up."

"Writing rubrics provide the teacher with the criteria to assess students' work, such as purpose, organization, grammar, and mechanics."

"A rubric is a useful, fast and accurate way of correcting writing tasks."

"From my point of view, motivating students to know their spelling weaknesses and correcting their own mistakes will significantly help them overcome their fear of falling into it and make writing fun."

3.4 Results of the Teachers' Perspectives on the Improvement of Writing after Using WSRs

The analysis of the responses to the fourth question, "How do the EFL teachers validate the improvement of their students' writing after using WSRs?" demonstrated the views of EFL teachers based on their experience and practical implications of WSRs in their writing classes. To illustrate the responses to the second open-ended question in the fourth section, the researchers categorized the quantitative data into (a) teachers who noticed an improvement in students' writing after using WSRs; (b) teachers who did not notice an improvement; and (c) teachers who were neutral (see Figure 3, below). 


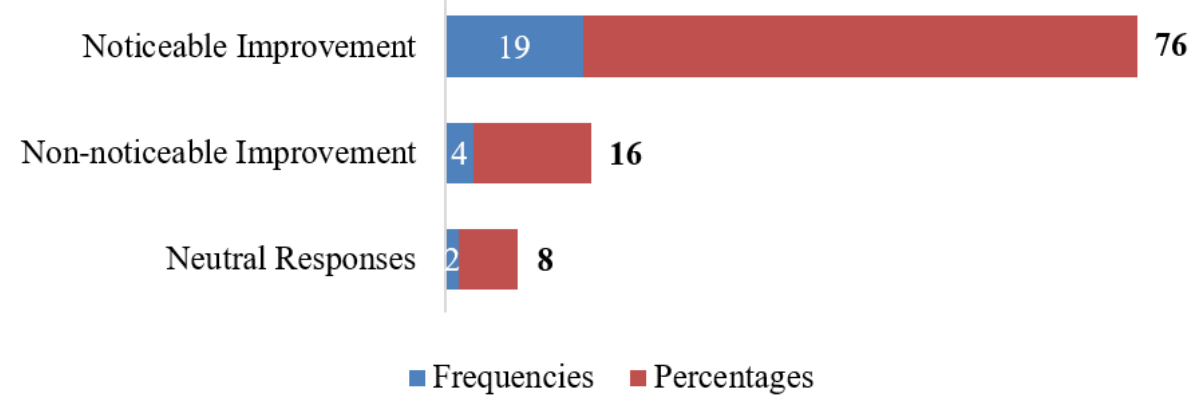

Figure 3. Descriptive Results of the Teachers' Perspectives on the Improvement of Students' Writing after Using WSRs

The results indicate that nineteen (76\%) noted an improvement and progress in their students' writing proficiency after using WSRs during their teaching, which might be evidenced by fewer mistakes, higher marks, or the good quality of their written texts. In contrast, four EFL teachers (16\%) did not, and two (8\%) were neutral.

Furthermore, the comments below reflect EFL teachers' perspectives on improving students' writing after using WSRs, based on a thorough qualitative data analysis.

"Rubrics show my pupils and me the sub-skills in writing that they need to learn. As a result, at the end of the session, unit, or semester, I usually know whether my students met the learning objectives or whether I used the best teaching approach. Furthermore, these rubrics assist me in determining the evaluation of students' writing; as a result, my students have a clear understanding of how their writing will be evaluated."

"WSRs contributed a lot to improve my students' level by helping them to know their deficiencies and focusing on them. It also helps the teacher to discover talented students."

"Providing the students with the rubrics increases their awareness of how they will be graded. Also, they know the correct ways of writing, including what is important and what is not."

"In fact, my students start to check their writing carefully before they send it. They know how I will evaluate their work, so make an effort to achieve a high score."

"After using rubrics as feedback, the students understood how I would assess their writing, and they followed these rubrics as a guide for their writing. I think rubrics help students avoid common mistakes if they use them well. It's a great tool for any teacher and student."

"I noticed that my students' grammatical mistakes lessened and the correct use of vocabulary increased. Actually, my students use rubrics as peer-assessment more than self-assessment."

\section{Discussion}

This mixed-method study examined the perspectives of Saudi EFL teachers concerning the use of WSRs to correct their students' written work and the practical implications for EFL writing classes.

The first research question in the second section found that the majority of Saudi EFL teachers preferred to correct students' written work in class rather than using customized WSRs, self-assessment, or journals and portfolios. This was due to their prior teaching experience or considering alternative assessment techniques as timeconsuming (i.e., peer editing, self-correction, and WSRs). These findings contrast with those of Narvaez et al. (2019), Qasim and Qasim (2015), Rini and Purnawarman (2018), and Sharma (2019), who found that EFL teachers believed WSRs to provide accurate assessments, as well as improving grading, student autonomy, evaluation, mechanical writing errors, and students' writing achievement. However, they support Aldukhayel's (2017) findings that students tend to be unfamiliar with WSRs and how rubrics are used in the classroom.

A further significant finding was that Saudi EFL teachers 'sometimes' use rubrics and 'usually' engage their students in designing personalized WSRs. These findings are in line with those of the first research question, in which EFL teachers reported infrequent use of WSRs, due to: firstly, their belief in the benefits of rubrics and the importance of involving learners in assessment criteria and secondly, that Saudi educators (i.e., decision-makers, supervisors, academic instructors, researchers, and teachers) are becoming increasingly concerned about implementing WSRs as a new trend in the Saudi educational system, as well as expanding their understanding of the importance of 
including students in creating more specific and familiar rubric criteria. These results are consistent with previous research (Gulzar et al., 2017; Qasim \& Qasim, 2015; Rini \& Purnawarman, 2018; Sharma, 2019), demonstrating that scoring rubrics improve teachers' capacity to make precise corrections, assessments, and grading while enhancing students' writing skills. They also support Aldukhayel (2017), Becker (2016), and Rini and Purnawarman (2018), who found that involving students in the creation of WSRs helped them comprehend learning expectations.

The most significant finding was that the Saudi EFL teachers acknowledged the importance of WSRs for improving students' performance through constructive feedback, encouraging critical thinking and self-assessment while addressing mistakes in spelling and punctuation. Moreover, WSRs also assist learners in identifying their writing difficulties and strengths and providing evidence of their writing performance. Furthermore, the responses to the remaining statements demonstrated that EFL teachers agreed on the importance of WSRs for identifying faults in grammar, mechanics, coherence, and handwriting and promoting higher-order thinking skills. Thus, this research can hypothesize that Saudi EFL teachers have a positive understanding and practical experience contributing to their favorable view of WSRs.

The results are also supported by the EFL teachers' responses to the first open-ended question, revealing that scoring rubrics improves students' writing, as well as helping them become more creative and critical thinkers, and increasing their enthusiasm for writing classes, mainly due to obtaining a clear understanding of their performance. These results also concur with those of Gulzar et al. (2017), Jeong (2015), Mahmoudi and Buğra (2020), Narvaez et al. (2019), Qasim and Qasim (2015), and Turgut and Kayaoğlu (2015), who concluded that scoring rubrics: assist EFL students to grasp the qualities of excellent writing; facilitate fair evaluation; report students' accomplishments; identify strengths and shortcomings, and providing learners with the ability to analyze their writing errors. Similarly, Saudi EFL teachers acknowledged the benefits of WSRs, particularly for: identifying students' creativity; planning appropriate activities; applying novel teaching writing strategies; reporting on students' progress, and accurately determining learners' writing outcomes.

The responses to the first open-ended question support the findings, with the EFL teachers stating that the scoring rubrics offer criteria to evaluate their students' work (i.e., purpose, organization, grammar, and mechanics) and being an effective correction technique. These results have been corroborated by Gulzar et al. (2017), Jeong (2015), Rini and Purnawarman (2018), and Sharma (2019), who confirmed that WSRs could increase teachers' ability to provide accurate assessments and positively influence students' writing achievement.

A further important finding was that the responses to the first open-ended question revealed that EFL teachers viewed WSRs as more beneficial for students. These results are consistent with Gulzar et al. (2017), Jeong (2015), Kulprasit (2016), Mahmoudi and Buğra (2020), and Turgut and Kayaoğlu (2015), who found WSRs enabled students to complete projects and improve their writing skills, as well as enhancing self-assessment, peer feedback, and grading procedures.

The second open-ended question indicated improvements in students' writing after using WSRs, helping them identify the writing subskills in need of practice, grasp how their writing works, and increase their awareness of writing qualities. Rubrics were also found to help teachers select effective teaching methods, identify gifted students, and determine evaluation criteria. These results are also in line with those observed in earlier studies.

\section{Conclusion and Recommendations}

This quantitative and qualitative study explored the perspectives of Saudi EFL teachers concerning the use of WSRs to correct students' written work. It also provided in-depth insights into the practical implications of using WSRs in EFL writing classes. The study sample included 106 Saudi EFL teachers who voluntarily participated in the questionnaire and answered the first open-ended question, with twenty-five answering the second open-ended question.

The research confirmed that a considerable number of previous studies (Anh, 2019; Ibnian, 2017; Javid \& Umer, 2014; Karim et al., 2017; Mohammed \& Alshenqeeti, 2020; Rass, 2015) had outlined the challenges facing EFL students and teachers in terms of written work (Alshakhi, 2018; Mohammad \& Hazarika, 2016; Onchera \& Manyasi, 2013). The literature review identified this as being due to students' lack of vocabulary, poor grammar, poor spelling, lack of research skills, attitudes, anxiety, and motivation.

The findings of the current study revealed the following. Firstly, Saudi EFL teachers frequently employ in-class correction and feedback, with nearly one-third using WRSs, self-assessment, peer editing, journals, and portfolios. Secondly, that Saudi EFL teachers believe WSRs primarily benefit students. Finally, WSRs might be viewed by some experienced EFL teachers as a practical correction or assessment method that improves students' writing. 
Therefore, this study establishes a framework for understanding teaching, learning, and assessing writing skills and contributes to a growing body of literature highlighting the difficulties facing teachers and students.

The results reveal two essential arguments. Firstly, Saudi EFL teachers rarely use WSRs, despite acknowledging their benefits to students and teachers. Secondly, that EFL teachers highlighted the importance of employing WSRs, due to these: (1) facilitating instruction; (2) assessing multiple types of writing essays; and (3) providing a reliable instrument for correcting errors in grammar, spelling, organization of ideas, word selection, and other sub-writing abilities.

These findings promote an understanding of the importance of WSRs to Saudi EFL teachers and students, including identifying the difficulties experienced in selecting appropriate methods and tactics, correcting, and grading writing skills. The study also offers the following theoretical implications and recommendations.

Firstly, to incorporate WSRs in Saudi EFL classrooms as an intrinsic aspect of teaching, assessing, and grading writing skills.

Secondly, the Ministry of Education should devote additional time, resources, and training in employing WSRs in EFL writing classes.

Thirdly, EFL teachers should improve their WSR implementation skills by creating customized versions that fit their learning objectives, students' proficiency levels, and other environmental (i.e., large classes, resources, administrative support) and psychological (attitudes, anxiety, motivation, readiness) factors.

Fourthly, EFL teachers should coach students to use WSRs for self-assessment and peer editing.

This study recommends that future research should: Firstly, assess the long-term effects of WSRs on EFL writing skills, including comparing the experiences of individuals at the same school level. Secondly, estimate the impact of WSRs on minimizing specific writing errors. Finally, be replicated with male and female EFL teachers and students to generate more profound insights into the value of WSRs in writing classrooms.

\section{Limitations of the Study}

Although this exploratory study did not aim to generalize to a larger population, it recognizes that its limitations includes: firstly, the limited sample size. Secondly, that participants consisted exclusively of Saudi female EFL teachers, resulting in the impact of gender being beyond this study's scope; Thirdly, the study was restricted to Medina, Saudi Arabia, indicating the need for further studies on a broader scale in the Saudi context to generalize the results. Finally, although participants were encouraged to respond honestly and ensured confidentiality, Saudi female EFL teachers may have responded to qualitative data with the 'appropriate' response but did not espouse that belief. In addition, researchers need to acknowledge that study participants can show what they think researchers wish to see.

\section{Acknowledgments}

Special thanks to all Saudi EFL female teachers at Medina, Saudi Arabia, who participated in this study for their invaluable responsiveness during the 2020 academic year.

\section{References}

Ahmed, A. H. (2010). Students' problems with cohesion and coherence in EFL essay writing in Egypt: Different perspectives. Literacy Information and Computer Education Journal (LICEJ), 1(4), 211-221. https://doi.org/10.20533/licej.2040.2589.2010.0030

Ahmed, F. (2019). Errors of unity and coherence in Saudi Arabian EFL university students' written paragraph: A case study of College of Science and Arts, Tanumah, King Khalid University, Kingdom of Saudi Arabia. European Journal of English Language Teaching, 4(3), 125-155. https://doi.org/10.5281/zenodo.321555

Aldukhayel, D. M. (2017). Exploring students' perspectives toward clarity and familiarity of writing scoring rubrics: The case of Saudi EFL students. English Language Teaching, 10(10), 1-9. https://doi.org/10.5539/elt.v10n10p1

Alshakhi, A. (2018). Revisiting the writing assessment process at a Saudi English language institute: Problems and solutions. English Language Teaching, 12(1), 176-185. https://doi.org/10.5539/elt.v12n1p176

Alshammari, S. (2020). "Writing to learn or learning to write". A critical review of "English as a foreign language" (EFL) teaching practices in writing in Saudi Universities. Research in Education and Learning Innovation Archives, 24, 1-22. https://doi.org/10.7203/realia.24.15867

Alzamil, A. (2020). An investigation of writing errors made by Saudi English-major students. International 
Journal of English Linguistics, 10(2), 92-97. https://doi.org/10.5539/ijel.v10n2p92

Anh, D. T. (2019). EFL student's writing skills: Challenges and remedies. IOSR Journal of Research \& Method in Education, 9(6 Ser. I.), 74-84. https://doi.org/10.9790/7388-0906017484

Ansari, A. A. (2012). Teaching of English to Arab students: Problems and remedies. Educational Research, 3(6), 519-524. Retrieved from http://www.interesjournals.org/ER

Anwar, M., \& Ahmed, N. (2016). Students' difficulties in learning writing skills in second language. Science International (Lahore), 28(4), 735-739.

Becker, A. (2016). Student-generated scoring rubrics: Examining their formative value for improving ESL students' writing performance. Assessing Writing, 29, 15-24. https://doi.org/10.1016/j.asw.2016.05.002

Bradford, K. L., Newland, A. C., Rule, A. C., \& Montgomery, S. E. (2016). Rubrics as a tool in writing instruction: Effects on the opinion essays of first and second graders. Early Childhood Education Journal, 44, 463-472. https://doi.org/10.1007/s10643-015-0727-0

Chan, Z., \& Ho, S. (2019). Good and bad practices in rubrics: The perspectives of students and educators. Assessment and Evaluation in Higher Education, 44(4), 533-545. https://doi.org/10.1080/02602938.2018.1522528

Chowdhury, F. (2018). Application of rubrics in the classroom: A vital tool for improvement in assessment, feedback and learning. International Education Studies, 12(1), 61-68. https://doi.org/10.5539/ies.v12n1p61

Creswell, J. W. (2012). Educational research: Planning, conducting, and evaluating quantitative and qualitative research. In Nursing Research. Pearson Education, Inc. https://doi.org/10.4324/9781315092171-19

Fareed, M., Ashraf, A., \& Bilal, M. (2016). ESL learners' writing skills: Problems, factors and suggestions. Journal of Education \& Social Sciences, 4(2:1), 83-94. https://doi.org/10.20547/jess0421604201

Gulzar, M. A., Buriro, G. A., \& Charan, A. A. (2017). Investigating the effects of rubrics on assessment of writing tasks. International Research Journal of Arts \& Humanities (IRJAH), 45(45), 191-206.

Ibnian, S. S. (2017). Writing difficulties encountered by Jordanian EFL learners. Asian Journal of Humanities and Social Studies, 05(03), 2321-2799. Retrieved from http://www.ajouronline.com

Ibrahim, N., \& Nambiar, R. (2011). What is the problem with the statement of problem?: The case of postgraduate international students and the introductory sections of a project paper. Procedia - Social and Behavioral Sciences, 15, 1713-1717. https://doi.org/10.1016/j.sbspro.2011.05.092

Jashari, L. T. \& Fojkar, M. D. (2019). Teachers' perceptions of developing writing skills in the EFL classroom. English Language and Literature Teaching, 16(2), 77-90. https://doi.org/10.4312/elope.16.2.77-90

Javid, C., \& Umer, M. (2014). Saudi EFL learners' writing Problems: A move towards solution. Proceeding of the Global Summit on Education GSE 2014 (E- ISBN 978-967-11768-5-6) 4-5 March 2014, Kuala Lumpur, MALAYSIA., 164-180. WorldConferences.net\%0A164

Jeong, H. (2015). Rubrics in the classroom: Do teachers really follow them? Language Testing in Asia, 5(6), 1-14. https://doi.org/10.1186/s40468-015-0013-5

Karim, S., Maasum, T., \& Latif, H. (2017). Writing challenges of Bangladeshi tertiary level EFL learners. Journal of Social Sciences and Humanities, 12(2), 296-306.

Kenta, A. E., \& Bosha, T. B. (2019). An investigation into factors that affect students' writing skills: The case of Sodo secondary school. English Language, Literature \& Culture, 4(2), 54-60. https://doi.org/10.11648/j.ellc.20190402.14

Ketabi, S. (2015). Different methods of assessing writing among EFL teachers in Iran. International Journal of Research Studies in Language Learning, 5(4), 1-14. https://doi.org/10.5861/ijrsll.2015.1161

Kulprasit, W. (2016). EFL students' attitudes toward authentic and formative assessment: The role of writing rubric. International Journal of Languages, Literature and Linguistics, 2(1), 32-37. https://doi.org/10.18178/ijll1.2016.2.1.63

Kulprasit, W. (2017). Writing rubric and three types of reflective writing feedback: students' attitude boosters. The European Proceedings of Social and Behavioural Sciences, 95-105. https://doi.org/10.15405/epsbs.2019.09.10

Larkin, T. L. (2015). A rubric to enrich student writing and understanding. International Journal of Engineering 
Pedagogy (IJEP), 5(2), 12. https://doi.org/10.3991/ijep.v5i2.4587

Mahmoudi, F., \& Buğra, C. (2020). The effects of using rubrics and face to face feedback in teaching writing skill in higher education. International Online Journal of Education and Teaching, 7(1), 150-158. Retrieved from http://iojet.org/index.php/IOJET/article/view/693

Mohammad, T., \& Hazarika, Z. (2016). Difficulties of learning EFL in KSA: Writing skills in context. International Journal of English Linguistics, 6(3), 105-117. https://doi.org/10.5539/ijel.v6n3p105

Mohammed, O., \& Alshenqeeti, H. (2020). E-journaling and Writer's Workshop as Writing Scaffolding Techniques in Saudi EFL Classes. Sohag University Journal of Education, 76, 37-58. https://doi.org/10.21608/edusohag.2020.103381

Moses, R. N., \& Mohamad, M. (2019). Challenges faced by students and teachers on writing skills in ESL contexts: A literature review. Creative Education, 10(13), 3385-3391. https://doi.org/10.4236/ce.2019.1013260

Moskal, B. M. (2000). Scoring rubrics: What, when and how? Practical Assessment, Research and Evaluation, 7(3), 1-5. https://doi.org/10.7275/a5vq-7q66

Narvaez, M., Salas, E., Basantes, E., Rodriguez, N., \& Escobar, M. (2019). Rubrics and academic performance in English as a foreign language teaching: Assessing writing tasks. European Scientific Journal ESJ, 15(17), 4660. https://doi.org/10.19044/esj.2019.v15n17p46

Neuman, W. L. (2014). Social research methods: Qualitative and quantitative approaches. In Teaching Sociology (7th ed.). Pearson Education Limited. https://doi.org/10.2307/3211488

Ningsih, S. (2016). Guided writing to improve the students' writing ability of junior high school students. EFL Journal, 1(2), 129-140. https://doi.org/10.21462/eflj.v1i2.12

Nuruzzaman, M., Islam, S., \& Shuchi, I. J. (2018). An analysis of errors committed by Saudi non-English major students in the English paragraph writing: A study of comparisons. Advances in Language and Literary Studies, 9(1), 31-39. https://doi.org/10.7575/aiac.alls.v.9n.1p.31

Onchera, P. O. \& Manyasi, B. N. (2013). Functional writing skills for effective communication: The English language classroom in Kenya. Journal of Emerging Trends in Educational Research and Policy Studies (JETERAPS), 4(6), 842-847.

Qasim, A., \& Qasim, Z. (2015). Using rubrics to assess writing: Pros and cons in Pakistani teachers' opinions. Journal of Literature,Languages and Linguistics, 16, 51-58. Retrieved from http://www.iiste.org/Journals/index.php/JLLL/article/viewFile/27152/27835

Rass, R. A. (2015). Challenges face Arab students in writing well-developed paragraphs in English. English Language Teaching, 8(10), 49-59. https://doi.org/10.5539/elt.v8n10p49

Ridha, N. S. (2012). The effect of EFL learners' mother tongue on their writings in English: An error analysis study. Journal of the College of Arts. University of Basrah No, 60, 22-45.

Rini, R., \& Purnawarman, P. (2018). Teachers' perception toward planning and implementing teacher-made rubrics of EFL students' writing assessment. Advances in Social Science, Education and Humanities Research, Volume 254 Eleventh Conference on Applied Linguistics (CONAPLIN 2018), 361-364. https://doi.org/10.2991/conaplin-18.2019.176

Setyowati, L., \& Sukmawan, S. (2016). EFL Indonesian students' attitude toward writing in English. Arab World English Journal, 7(4), 365-378. https://doi.org/10.2139/ssrn.2898636

Sharma, V. (2019). Teacher perspicacity to using rubrics in students' EFL learning and assessment. Journal of English Language Teaching and Applied Linguistics, 1(1), 16-31.

Tseng, C. T. H. (2018). Delayed effect of teachers' error correction on EFL students' ability in self-correction in writing: A case study. International Journal of Language \& Linguistics, 5(4), 159-165. https://doi.org/10.30845/ijll.v5n4p20

Turgut, F., \& Kayaoğlu, M. (2015). Using rubrics as an instructional tool in EFL writing courses. Journal of Language and Linguistic Studies, 11(1), 47-58. Retrieved from http://www.jlls.org/index.php/jlls/article/view/4/5 


\section{Copyrights}

Copyright for this article is retained by the author(s), with first publication rights granted to the journal.

This is an open-access article distributed under the terms and conditions of the Creative Commons Attribution license (http://creativecommons.org/licenses/by/4.0/). 